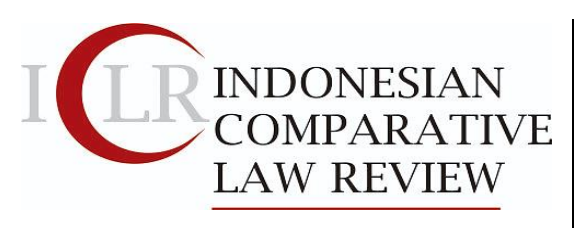

Volume 1 No 2, June 2019

P-ISSN: 2655-2353, E-ISSN: 2655-6545
Article Info:

Received : 24-05-2019

Revised : :02-06-2019

Accepted : 18-06-2019

\title{
THE SALAD DAYS OF THE EU DIGITAL SERVICES TAX
}

\section{Adrianto Dwi Nugroho'}

Universitas Gadjah Mada, Indonesia

E-mail: adrianto.dwi@mail.ugm.ac.id

${ }^{1}$ Associate Professor in tax law at the Faculty of Law, Universitas Gadjah Mada (Yogyakarta, Indonesia). Doctoral student at the Faculty of Law, University of Helsinki (Helsinki, Finland). The author wishes to thank Professor Marjaana Helminen for her precious comments. E-mail: adrianto.dwi[at]mail.ugm.ac.id

\begin{abstract}
Responding to a series of aggressive tax planning allegedly committed by multinational corporations running their businesses on digital platforms, states have drafted laws that would enable them to impose additional taxes on such corporations. In the EU, the proposal for a Council Directive on the Digital Services Tax (DST) projects for a 3\% tax chargeable on the revenues generated by corporations surpassing a certain threshold of global and EU yearly revenues. The initial plan is to tax these corporations for their online placement of advertising, enabling of online marketplaces, and sales of collected user data. While the EU organs are still undergoing the due legislative processes on the proposal, two flaws of the DST may be argued, namely that it conflates features of direct taxes (i.e.
\end{abstract}

income tax) with that of indirect taxes (i.e. value-added tax); and that it embeds covert discriminatory measures against certain multinational corporations. The maturation of the DST depends on the formulation of sound legal principles and ingenious concept, which would hallmark a DST regime from the corporate income tax one.

Keywords: EU, Digital Services Tax (DST)

\section{Introduction}

The Digital Services Tax (hereinafter, DST) is currently living its salad days. A draft of DST law submitted by the European Commission has demonstrated the lack of experiences and underlying principles of the DST. It is due to the fact that the DST will only be an interim regime before a Council Directive on rules relating to the corporate taxation of a significant digital presence ${ }^{1}$ is enacted and became effective.

1 The European Commission, 'Proposal for a Council Directive laying down rules relating to the corporate taxation of a significant digital presence', $\operatorname{COM}(2018)$ 147, 21 March 2018, Article 4(3). In the proposal, a 'significant digital presence' is to be determined in accordance with a corporation's total revenues, total number of users, and total number of business contracts generated in an EU Member State. 
Legislators are, therefore, not incentivised to put as many efforts as rather permanent legislation would demand. Also, this is because the draft of DST law is based on responsive tax policy. The policy underlying the proposal aims at surmounting the 'misalignment between the place where the profits are taxed and the place where value is created.'2 Thus, within the DST, it is the rules on value creation that dictate the allocation of profits among states. The current international tax rules are considered as failing to '(...) acknowledge the role of [digital platform] users in generating value for digital companies by providing data and content or as the building blocks of the networks that are central to many digital business models.' ${ }^{3}$ In other words, within the digital economy, value is created in the state in which the users of digital services reside.

Commenting on the UK DST proposal, Professor Deveraux ${ }^{4}$ criticised that userbased value creation lacks clear rationales under the existing principles. He asserted that 'value creation' includes a vast array of variables, as such that a DST-or similarregime cannot be justified by the principles of fairness and economic efficiency. Arguably, the EU DST concept is also

2 The European Commission, 'Proposal for a Council Directive on the common system of a digital services tax on revenues resulting from the provision of certain digital services', COM(2018) 148, 21 March 2018, 2.

3 The European Commission, 'Communication from the Commission to the European Parliament and the Council concerning Time to establish a modern, fair and efficient taxation standard for the digital economy', COM(2018) 146, 21 March 2018, 4.

4 Michael Deveraux, "The Digital Services "Sutton" Tax',

http://businesstaxation.sbsblogs.co.uk/2018/10/23/t he-digital-services-sutton tax/?dm_i=17AR,5XL76,U06BYQ,N8496,1, December 2018]. unjustifiable by the aims to protect the integrity and ensure the proper functioning of the single market, as well as the need to ensure sustainability of the EU public finances, as set out in the Commission's proposal. Thus, is the current EU proposal for a DST feasible? If not, what might improve its feasibility?

\section{Methodology}

This article is based on the doctrinal research conducted by the author. Materials scrutinised in the study comprises of primary references, such as the European Commission's proposals for Council Directives on DST, and secondary references. Discussions brought upon by Michael Devereux on the subject matter are amongst the most scrutinized secondary references in this article.

\section{Disproportionate measures within} the EU DST proposal

It is not contested that the transformation carried out by the digital economy on the method by which people interact, consume, and do businesses require for tax measures that would bring about fair taxation and economic efficiency. Paradoxically, the standards by which a DST will be imposed are resulted from a simple " face-lifting' of the established corporate income tax (CIT) system, with additional influences from the Value Added Tax (VAT) system. It is insufficient to cherry-pick CIT and VAT features that benefit the states' revenues the most and develop a new type of tax that aims at equalising the amount which would otherwise be paid as CIT. Furthermore, it is not acceptable to enforce a tax regime whose subjective qualifications 
can only be met by certain taxpayers. After all, '(...) devising rules specifically for the digital economy may well be inappropriate, ${ }^{5}$ although digitalisation has made it easier for multinational corporations to set up their entities and shift their profits to low-tax jurisdictions. ${ }^{6}$ It is arguably the case with the DST proposal, which has significantly contributed to the architectural flaws of the tax. These flaws are coherent to, again, the responsive and temporary nature of the DST, in lieu of a comprehensive and long-term solution.

2.1. The conflation of concepts established in direct and indirect taxes

The first flaw of the DST concerns its embodiment of tax principles found in the CIT and VAT systems, whereas the CIT, VAT, and DST are syntheses of distinct international tax paradigms. The CIT is based on the principle of 'origin', by which business profits are generated in the state in which capital and labour are deployed as means of producing goods or services (i.e. the emphasis on the supply side of income production). ${ }^{7}$ The nexus for taxation on business profits is thus allocated to that state, unless a permanent establishment exists in the state in which the goods or

5 Maarten de Wilde, 'Tax jurisdiction in a digitalizing economy; why 'online profits' are so hard to pin down', (2015) 43 Intertax 796, 801.

6 Michael P. Devereux and John Vella, 'Implications of digitalization for international corporate tax reform', (2018) 46 Intertax 550, 551.

7 Maarten de Wilde, supra 5, 797. See also: OECD, 'Addressing base erosion and profits shifting', (OECD Publishing 2012), 35. The OECD upholds the 'origin of wealth' principle, by which taxation of business profits are determined by “(...) (i) the origin of the wealth (i.e. source) and (ii) where the wealth was spent (i.e. residence)." The origin of wealth thus represents "(...) all the stages involved in the creation of wealth." services are destined. One should reckon that the CIT was designed with sound tax principles and policy objectives, including to facilitate cross-border trades through avoidance of double taxation.

Meanwhile, the DST is conceptually based on the principle of 'destination, by which business profits may-depending on whether sales are actually made-be generated in the state in which the produced goods or services are distributed to the market (i.e., the emphasis on the demand side of income production). ${ }^{8}$ In turn, the principle is paving the way for 'value creation', which was reiterated in the Base Erosion and Profits Shifting (BEPS) project as means to tackle ' $(. .$.$) the use of intangibles,$ risks, capital, and other high-risk transactions to shift profits. ${ }^{9}$ Battling for its way to overtake the hegemony of permanent establishment in determining the nexus for source taxation on business profits, value creation might have found its armours in the DST. Unfortunately, the DST is a mere twist of the CIT and with prejudice to the nature of opportunities for double non-taxation.

The destination principle has been the backbone of the VAT system. By design, the VAT burden is meant to be carried by the consumers, thus has its emphasis on the demand side of income production. Recent literature has, however, sought for discussions on the Destination-Based Cash Flow Tax (DBCFT), which is also an attempt for an adjusted adoption of the destination principle into the direct tax system. The DBCFT is claimed to have the ability to, inter

\footnotetext{
8 Maarten de Wilde, supra 5, 798.

9 See: OECD, 'Action plan on base erosion and profits shifting', (OECD Publishing 2013), 14.
} 
alia, remove the incentives for taxpayers to manipulate internal transfer prices and eliminate taxation on business profits in the residence states, both of which through the so-called 'border adjustments'. ${ }^{10}$

A slightly less adjusted incorporation of the destination principle is, however, found within the conceptualization of the DST. On the one hand, the DST has posited multinational corporations as carriers of its economic and administrative burdens - thus attributes the DST with character of a direct tax, like the CIT. On the other hand, the DST is calculated based on the value of turnovers (i.e. the gross revenues) - thus attributes the DST with the character of an indirect tax, like the VAT. Its emphasis on the taxable objects (i.e. the taxable revenues) is also unusual for taxation on persons like the DST. Indeed, in its proposal, the Commission formulates the tax base of DST as to include '(...) total gross revenues, net of value-added tax and other similar taxes'11 derived from: ${ }^{12}$

(a) the placing on a digital interface of advertising targeted at users of that interface;

(b) the making available to users of a multisided digital interface which allows users to find other users and to interact with them, and which may also facilitate the provision of underlying supplies of goods or services directly between users; and

10 Alan Auerbach, 'Understanding the destinationbased approach to business taxation', 26 October 2017, https://voxeu.org/article/understanding-destination-basedapproach-business-taxation, on 21 December 2018.

11 The European Commission, $\operatorname{COM}(2018)$ 148, supra

2, proposed Article 3(2).

12 The European Commission, COM(2018) 148, supra

2, proposed Article 3(1). (c) the transmission of data collected about users and generated from users' activities on digital interfaces.'

As further explained in the next section, the above activities have been redefined as to restrict the type of activities - the revenues of which are - to be taxed with DST. At this point, it is necessary to identify that, based on the above formulation of activities, the Commission seeks to include a vast array of business models followed by operators within the digital economy. The Commission, however, neglects the cascade effect inherent to turnover-based taxes. The European Economic and Social Committee (EESC), while identifying this as a potential issue, submits: ${ }^{13}$

'The EESC is concerned that by taxing turnover, with the negative cascading effects explicitly recognised by the Commission, the development of digital services, and in particular start-ups, could be harmed. The cascading effect arises when the services are sold several times and taxed each time.'

Indeed, more issues concerning the cascade effect of indirect taxes arise in the business-to-business (B2B) model than in the business-to-consumer (B2C) model, which major digital economy operators embrace the most. At this point, a destination-based tax has gained support in that consumers are relatively immobile, and that such taxation might be the only viable option even in the long term. ${ }^{14}$ The B2C model, however,

13 Opinion of the European Economic and Social Committee on 'Proposal for a Council Directive laying down rules relating to the corporate taxation of a significant digital presence', OJ C 367/73, [3.13].

14 Michael P. Devereux and John Vella, supra 6, 555556. Also, a destination-based taxation on profits strongly relates to the protection of intellectual 
presents another challenge of imposing DST, namely the collection of taxes. Obliging private customers to withhold the DST during the delivery of goods or services by virtue of digital platforms would present technical challenges, which in turn hinder the pursuit of an efficient tax collection system. At this point, taxing corporate profits by way of imposing indirect taxes seems to be disproportionate to establish a fair tax system.

More disproportionate is the imposition of DST on gross corporate income. In this regard, one should reckon that direct taxes, be it income tax or DST, embrace the equity principle, by which the amount of taxes payable should accord with the ability to pay of the payer. In the income tax, this translates to measures such as exempted income, income brackets, and for entrepreneurs, the calculation of tax base on a net basis. Practically, the income tax laws allow for taxation on gross income only for the so-called passive income, that is to say, income derived from the passive use of capital (i.e. portfolio investments), such as dividends, interests, and royalties. The costs incurred in acquiring these incomes are usually low or indeterminable that grossincome taxation is justified. It is not the case with business profits, which calculation for income tax must account for all costs deductible by virtue of the income tax laws. It is doubtful that the temporary effect of DST and the need to establish a fair tax system are sufficient in justifying grossincome taxation in DST. Unfortunately, the disproportionateness of the DST does not

property rights by the state in which the products are marketed. end at the conflation of tax concepts.

2.1. The liquefied concept of 'value creation'

The above conceptual flaws have led to disproportionate tax measures. The rapid growth of the digital economy is considered paramount that a responsive standard like the DST is urgently necessary to be implemented. Recent exposures of alleged tax evasions by actors of the digital economy later furnish for the retributive elements of the DST. Amongst the most sceptically disproportionate measures within the DST are whether the notion of value creation aligns with a turnover-based tax the DST is and whether the proposed rules on taxable persons for DST purposes constitute discriminatory measures against digital economy operators established in individual states.

As previously concluded, a turnoverbased tax is disproportionate to the goal of establishing a fair tax system within the EU. Presumably, such method has been chosen by the Commission within the efforts to align taxation of business profits with value creation. The Commission argued that values are created in the state where the users are located, for 'Users are providing data, sharing knowledge and content, and enabling wide and diverse networks.' ${ }^{15}$ In other words, these users have created 'customer-based intangibles,' which are essential in accruing business values of multinational corporations, even when not

15 The European Commission, COM(2018) 146, supra 3,1 . 
operating digitally. ${ }^{16}$ The EESC, however, argues: ${ }^{17}$

'Taxing turnover instead of profit and levying taxes where sales take place instead of where value is created a fundamental change from the current principles of taxation. (...) a shift in taxation will benefit larger economies with many consumers at the expense of smaller exporting economies. The EESC underlines that any solution, whether short or long term, to the taxation of digital business models, must result in a fair and equal economic outcome for all economies in the EU.'

Effectively, the EESC reaffirms that a turnover-based tax is rather radical from the existing international tax law principles, and more significantly, that values are not created in the state in which the users are residing. While the latter conclusion raises the concern of the possible departure of taxable income from one Member State to another, it posits the caveat of a distorted EU single market which is less attractive than emerging markets that do not impose a DST. If this conclusion is unlikely to occur, the imposition of value-creation-based DST will at least distort the balanced allocation of taxing rights established by the current networks of Double Tax Conventions (DTC). Conclusively, the EU considers itself as home of the investors - and thus retains the unrestricted taxing right afforded by the provisions of DTC - in respect of inbound flows dividends and interests (and perhaps, royalties), while simultaneously affirms itself as home of the investments - and thus insists on acquiring primary taxing right, notwithstanding the provisions of DTC-in

16 Michael P. Devereux and John Vella, supra 6, 555556.

17 Opinion of the European Economic and Social Committee, supra 13, [3.15]. respect of business profits arguably generated in its territories. This constitutes a new level of tax sovereignty.

2.2. The covertly discriminatory policies and measures

The objective of a fair tax system is also unlikely to be achieved if the very means used in completing that goal is discriminatory. In its earlier studies on the DST, the Commission stated: 18

Digital companies are growing far faster than the economy at large, and the most extensive digital companies have huge user and consumer bases within the EU. For example, $42 \%$ of Europeans are users of Facebook. (...) the lion's share of the traffic is captured by the (...) global websites.

Perhaps, the naming as above is just illustrative. Even if it is typological, it is only mentioned in a policy paper, and thus hardly forms a discriminatory treatment. After all, the Commission had committed to abandon 'protectionism, deregulation or a race to the bottom' and shift its digital economy policies towards 'smart regulation.' 19 Tax policies in the EU should, therefore, represent a balanced response against the challenges brought upon by digitalisation and new business models. ${ }^{20}$

The targeting of foreign digital operator establishments is, however, reflected in the recitals and provisions of the proposed directive. Recital 22 of the proposed directive confers that 'only certain entities should qualify as taxable persons for DST, regardless of whether they are

18 The European Commission, $\operatorname{COM}(2018)$ 146, supra 3,2 .

19 The European Commission, $\operatorname{COM}(2018)$ 146, supra 3,3 .

20 The European Commission, $\operatorname{COM}(2018)$ 146, supra 3, 3-4. 
established in a Member State or a nonUnion jurisdiction.' The latter part of the phrase ensures that no overt discrimination arises. Covert discrimination, however, occurs when the proposed directive sets for a global revenue threshold of EUR $750,000,000$ and EU revenue threshold of EUR 50,000 in a given fiscal year. ${ }^{21}$ The revenue thresholds seem to operate similarly as thresholds establishing permanent establishments would work. A monetary threshold as such is, however, alien to the DTC. Temporary threshold (e.g. a certain number of months beyond which a construction project would constitute a permanent establishment) or qualitative thresholds (e.g. the dependency of an agent to a principal) are more common to be used as means to establish a permanent establishment. Again, a depart from established direct tax rules.

Furthermore, had a provision as such been adopted by an EU Member State, it would have invited for state aid investigation, or brought before the Court of Justice of the EU (CJEU) for a preliminary ruling on its conformity with the fundamental freedoms. When applied as an EU law, it would at least be a ring-fencing of the smaller business entities operating on digital platforms and have their customers within the EU territory. It follows that the Commission's commitment to avoid protectionism has not been reflected in the DST proposal. The only way to comprehend the revenue threshold is to consider the DST

21 The European Commission, COM(2018) 148, supra 2, Recital [22] and proposed Article 4(1). as an indirect tax. The VAT Directive, ${ }^{22}$ for example, confers for monetary thresholds on the total value of supply of goods (e.g., EUR 10,000 intra-EU acquisition threshold). Such measure is, again, incompatible for a tax whose policy is based on the failure of the states in which sales are made to tax profits of digital corporations, only due to the inability of these states to formulate 'physical presence' required by the existing corporate tax system.

\section{Proportioning the EU DST proposal}

In their joint statement on the establishment of fair and effective taxation in the EU for multinational corporations running their businesses through digital platforms, the governments of Germany and France have requested the Commission and the Council to focus the DST proposal on revenues generated from advertisement activities. 23 This statement consequently narrows the issues discussed in the previous section, among other things that fewer entities will be treated discriminatorily under the DST regime. The explanation is also well-reasoned, for advertising income has become a dominant income source of digital corporations. ${ }^{24}$ The business model has been that users consume the services provided by digital corporation, while

\footnotetext{
22 Council Directive 2006/112/EC of 28 November 2006 on the common system of value added tax, OJ L $347 / 1$

$23 \mathrm{NN}$, 'Franco-German joint declaration on the taxation of digital companies and minimum taxation', available at https://www.consilium.europa.eu/media/37276/frde-joint-declaration-on-the-taxation-of- digitalcompanies-final.pdf [31 December 2018].

24 Hans Jarle Kind and Marko Koethenburger, 'Taxation in digital media markets', (2018) 20 Journal of Public Economy Theory 22, 23.
} 
advertisers will place their ads and pay for the fees - which are linear to the number of users - charged by the digital corporation. ${ }^{25}$

Thus, it is the very technical ability of a digital corporation to manage the intergroup networks (i.e., systems of users and advertisers) that are critical to its revenue. ${ }^{26}$ While the ability is reflected in the number of users, it is also reflected in the number of infrastructural investments (e.g. the capacity of its servers) made by the corporation which may be located elsewhere than in the state in which a significant amount of its users reside. The prevailing view of the Commission seems to be, however, to deem revenues solely generated in the state of the users. In the long run, a one-sided view as such could harm commercial relationships between the EU and its partners, mainly when resulted in the former acquiring new right to tax profits of foreign corporations. The EESC notes: ${ }^{27}$

It is imperative to develop new principles on how to attribute corporate profits to an EU country and impose them, in dialogue with trading partners, in order to avoid any escalation of trade and tax tensions between major economic players in the world. The EESC underlines the need for appropriate and consensus-based solutions.

Fortunately, the EU Parliament has improved the texts of the proposal. In its proposed draft, the Parliament argues, inter alia, that 'digitalisation has changed the role of users, allowing them to become increasingly involved in the value creation process', with a purview of closing the gap

25 Hans Jarle Kind and Marko Koethenburger, supra $24,23$.

26 Hans Jarle Kind and Marko Koethenburger, supra $24,23$.

27 Opinion of the European Economic and Social Committee, supra 13, [3.7]. between the taxation of revenues generated from digital and non-digital platforms. ${ }^{28}$ The Parliament also reduces the EU revenues threshold to EUR 40,000,000. ${ }^{29}$ Within the next stages of the legislative process, the Commission and the Council should also align their work with the existing multilateral efforts in addressing tax issues within the digital economy. The EESC submits: ${ }^{30}$

When assessing the effective level of taxation of the digital sector, the EESC underlines the need to take into account the changes in the tax codes going forward due to the ongoing implementation of BEPS rules, and, in particular, to consider the substantially increased level of taxation in the US of US digital firms operating in the EU, due to changes in the US Tax Code.

The efforts to proportionate the DST proposal thus do not need to deviate from the current international frameworks, although ingenious solutions - and not just mere conflations of existing concepts-are necessary. Amongst the feasible solutions are to harness the current ideas of permanent establishment and royalties, as to include activities conducted in the digital economy.

\section{a. Harnessing the concept of permanent es- tablishment}

As previously mentioned, the idea of a DST was based on the difficulties faced by

28 The European Parliament, 'European Parliament legislative resolution of 13 December 2018 on the proposal for a Council directive on the common system of a digital services tax on revenues resulting from the provision of certain digital services', Amendment 2-3.

29 The European Parliament, supra 28, Amendment 37.

30 Opinion of the European Economic and Social Committee, supra 13, [3.14]. 
the states in which users of digital platforms reside to tax on the profits deemed to be generated by digital corporations out of their users. It has been the central scrutiny within the proposed Council Directive on rules relating to the corporate taxation of a significant digital presence, which is parallel to the proposal for DST Directive. While the latter measure is interim, the recent directive is expected to be permanent. In that directive, the notion 'significant digital presence' is introduced as means to qualify digital platforms as permanent establishments, the existence of which will induce taxation of profits by the state in which the establishments are located.

In determining the digital presence, the Commission has proposed for thresholds on total revenue, number of users and number of business contracts concluded by a digital corporation within an EU Member State. While these measures are novel to the traditional permanent establishments, they are necessary for rendering the international tax rules adaptive to the rapid changes towards business platforms. Perhaps, the revenue threshold, as previously argued, is incompatible with the direct-tax nature of the DST. Notwithstanding, the EESC supports for the measure, although it proposes for increase in the threshold. The setting of the threshold should '(...) resulted in an outcome that does not risk hampering digitalisation but instead enhanced the functioning of the single market.' ${ }^{31}$

31 Opinion of the European Economic and Social Committee, supra 13, [3.14]. b. Harnessing the concept of royalties

While taxation of profits of digital corporations is likely to be resolved by the thought of permanent establishment, studies can also be devoted to tax such profits by way of harnessing the international tax concept of royalties. It is made possible by the argument that users database constitute intangibles necessary in capitalising revenues within the digital economy. The values of users database are known as 'installed customer base', 'customer relations', or 'goodwill'. ${ }^{32}$

Practically, there are advantages in taxing the royalties derived from the users' database. First, the efforts to link value creation with the location of users may finally found success: users database are intangibles that are developed over time, taking into account the costs of infrastructural investments incurred by digital corporations in maintaining the values of the database. Second, taxing the royalties arising from the deployment of users database would only call for expansion to the current definition of royalties contained in the DTC. Doing so would avoid the introduction of measures alien to the current international tax regime, thus requires less political support. Lastly, while deploying the number of users as threshold for the creation of permanent establishment could lead to a state having taxing right in one year and not having one in another, taxing the income arising from the use of users database ensures stable taxing right for a state. The increase or decrease in the number of users would only affect the

32 Michael P. Devereux and John Vella, supra 6, 555. 
amount of taxes to be collected and not the taxing right.

\section{Conclusion}

Based on the above elaboration, and as the answer to the first question of this article, it can be concluded that the current EU DST proposal by the Commission is not feasible to be adopted. Conceptual flaws have led to the measures being disproportionate with the need to establish a fair tax system. For one reason, the proposed measures have instead blatantly adopted features of indirect taxes, taking into account the aim of the Commission to tax profits of digital corporations operating in the EU, a direct tax. The ambiguous genre of the charge is resulted from the introduction of a concept by which fees must be paid in the state or states in which values (i.e. a significant portion of the profits) are deemed to have been generated, or the so-called 'value creation' concept. Unfortunately, the Commission and the EESC have differences in comprehending the concept.

For another reason, as a result of the above conflation, the proposed measures are at least covertly discriminatory against major digital corporations established outside the EU and have their customer bases within the EU. In doing so, the Commission has introduced revenue thresholds within which business entities are not subject to DST. Simultaneously, these thresholds might also be seen as the Commission's efforts to ringfence the smaller enterprises established and operating within the EU. The discrimination may be unseen by those who view the DST as a substantial indirect tax, which the DST is not. Revenue thresholds are typical to indirect taxes, particularly in order to mitigate the complication resulted from their cascade effects. This complication is, however, atypical to direct taxes. Revenue thresholds introduced in these taxes are meant to implement the ability to pay principle, which is more relevant in individual income taxes than in CIT.

Meanwhile, as the answer to the second question of this article, it can be concluded that efforts to balance the DST measures with their goal of establishing a fair tax system have evidently been done by the EU Parliament. Users of digital platforms are considered as an essential contributor to value creation, but not the only contributor; while revenue thresholds have been lowered. A proportionate DST would, however, call for further efforts. A direct tax on the corporate profits of digital corporations should accord with the established international tax laws, particularly the DTC. The fee should be imposed as income tax as governed by provisions of DTC. In turn, a harnessed concept of permanent establishment should be able to formulate a 'physical presence' or other qualitative thresholds for digital corporations. Alternatively, efforts may also be devoted as to harness the concept of royalties within DTC, for arguments have been raised as to consider users database as intangibles - thus generate royalties payments. As a closure, it has been said that the law always comes behind than the developments-and the legal problems arising from there-taken place in the society. However, the law should not be formulated as means to establish a leeway, but rather as a dignified and comprehensive 
response to the legal issues confronted by the people.

\section{References}

\section{Books with an author}

Maarten de Wilde. (2015). 'Tax jurisdiction in a digitalizing economy; why 'online profits' are so hard to pin down'. 43 Intertax 796, 801.

Michael P. Devereux and John Vella. (2018). 'Implications of digitalization for international corporate tax reform'. 46 Intertax 550, 551.

Maarten de Wilde, supra 5, 797. See also: OECD, 'Addressing base erosion and profits shifting', (OECD Publishing 2012), 35. The OECD upholds the 'origin of wealth' principle, by which taxation of business profits are determined by “(...) (i) the origin of the wealth (i.e. source) and (ii) where the wealth was spent (i.e. residence)." The origin of wealth thus represents "(...) all the stages involved in the creation of wealth."

Michael P. Devereux and John Vella, supra 6, 555-556. Also, a destination-based taxation on profits strongly relates to the protection of intellectual property rights by the state in which the products are marketed.

\section{Law/Bill:}

Council Directive 2006/112/EC of 28 November 2006 on the common system of value added tax, OJ L 347/1.Opinion of the European Economic and Social Committee on 'Proposal for a Council Directive laying down rules relating to the corporate taxation of a significant digital presence', OJ C 367/73, [3.13].

The European Commission, 'Communication from the Commission to the European Parliament and the Council concerning Time to establish a modern, fair and efficient taxation standard for the digital economy', $\operatorname{COM}(2018)$ 146, 21 March 2018, 4.

The European Commission, 'Proposal for a Council Directive laying down rules relating to the corporate taxation of a significant digital presence', $\operatorname{COM}(2018)$ 147, 21 March 2018, Article 4(3). In the proposal, a 'significant digital presence' is to be determined in accordance with a corporation's total revenues, total number of users, and total number of business contracts generated in an EU Member State.
The European Commission, 'Proposal for a Council Directive on the common system of a digital services tax on revenues resulting from the provision of certain digital services', $\operatorname{COM}(2018)$ 148, 21 March 2018, 2.

\section{Books with an editor:}

The European Parliament, 'European Parliament legislative resolution of 13 December 2018 on the proposal for a Council directive on the common system of a digital services tax on revenues resulting from the provision of certain digital services', Amendment 2-3.

\section{Journal articles:}

Hans Jarle Kind and Marko Koethenburger. (2018). , 'Taxation in digital media markets', 20 Journal of Public Economy Theory 22, 23.

\section{World Wide Web:}

Alan Auerbach, 'Understanding the destination-based approach to business taxation', 26 October 2017, https://voxeu.org/article/understanding-destinationbased-approach-business-taxation, on 21 December 2018.

Michael Deveraux, 'The Digital Services “Sutton" Tax', http://business-

taxation.sbsblogs.co.uk/2018/10/23/the-digitalservices-suttontax/?dm_i=17AR,5XL76,U06BYQ,N8496,1, December 2018].

NN, 'Franco-German joint declaration on the taxation of digital companies and minimum taxation', available at https://www.consilium.europa.eu/media/37276/fr-dejoint-declaration-on-the-taxation-of-digitalcompanies-final.pdf [31 December 2018]. 